Revista Brasileira de

Engenharia Agrícola e Ambiental

v.16, n.5, p.487-495, 2012

Campina Grande, PB, UAEA/UFCG - http://www.agriambi.com.br

agriambi

Protocolo 098.10 - 27/05/2010 • Aprovado em 24/02/2012

\title{
Soil microbial biomass under different tillage and levels of applied pig slurry
}

\author{
Elcio L. Balota ${ }^{1}, 0$ swaldo Machineski ${ }^{1} \&$ Maria A. Matos ${ }^{1}$
}

\begin{abstract}
The objective of this work was to evaluate the changes in microbial biomass $C, N$ and $P$ due to the application of pig slurry under different soil tillage systems. The experiment was established in a clayey O xisol, Eutrophic Red Latossol in Palotina, PR. Different quantities of pig slurry $(0,30,60$ and $120 \mathrm{~m}^{3} \mathrm{ha}^{-1}$ year ${ }^{-1}$ ) were applied to the soil prior to the summer and winter crop season under conventional tillage (CT) and no tillage (NT), in three replicates. The area was cultivated with soybean (Glycine max L.) or maize (Zea mays L.) in the summer and wheat (Triticum sativum Lam.) or oat (Avena sativa L.) in the winter. The soil samples were collected in M arch and O ctober of 1998 and 1999 at depths of $0-5,5-10$ and $10-20 \mathrm{~cm}$. The soil tillage and pig slurry application influenced the microbial biomass $\mathrm{C}, \mathrm{N}$ and $\mathrm{P}$. The microbial biomass and the microbial activity presented high sensibility to detect changes in the soil due to tillage and the application of pig slurry. The soil microbial biomass and $\mathrm{C}_{\text {mic }} / \mathrm{C}_{\text {org }}$ relation increased as the quantity of applied pig slurry increased. The metabolic quotient under $\mathrm{CT}$ increased with depth while under N T it decreased. The soil microbial biomass was enriched in N and P under NT and as the quantity of applied pig slurry increased.
\end{abstract}

Key words: microbial activity, swine manure, soil management, nutrient cycling

\section{Biomassa microbiana em solo submetido a diferentes preparos do solo e adição de dejetos líquidos de suínos}

RESU M O

Foram avaliadas, no presente trabalho, as alterações na biomassa microbiana devido à aplicação de doses crescentes de dejetos líquidos de suínos (DLS) em diferentes sistemas de preparo de solo. 0 experimento foi conduzido em um Latossolo Vermelho eutrófico textura argilosa, em Palotina, PR; diferentes doses de dejetos líquidos de suínos (0, 30, 60 e $\left.120 \mathrm{~m}^{3} \mathrm{ha}^{-1} \mathrm{ano}^{-1}\right)$ foram aplicadas antes das estações de verão e inverno em sistema de preparo do solo convencional $(\mathrm{PC})$ e sistema de plantio direto (PD), em três repetições. 0 experimento foi conduzido com a cultura de soja ou milho no verão e trigo ou aveia no inverno. As amostras de solo foram coletadas em março e outubro de 1998 e 1999 nas profundidades de 0-5, 5-10 e 10-20 cm. O preparo do solo e as diferentes doses de DLS influenciaram 0 teor de $\mathrm{C}, \mathrm{N}$ e $\mathrm{P}$ da biomassa microbiana. A biomassa microbiana e sua atividade apresentaram boa sensibilidade para detectar alterações no solo, devido ao manejo. A biomassa microbiana e a relação $\mathrm{C}_{\text {mic }} / \mathrm{C}_{\text {org }}$ foram aumentadas com a aplicação crescente de DLS. O quociente metabólico sob PC aumentou em profundidade ocorrendo o inverso sob PD. A biomassa microbiana foi enriquecida com $N$ e $P$ em virtude das doses crescentes de dejetos líquidos de suínos.

Palavras-chave: atividade microbiana, resíduos de suínos, plantio direto, ciclagem de nutrientes 


\section{INTRODUCTION}

Swine production is one of the principal sources of income in certain regions of Brazil and a large part of the production is on small farms. Brazil is the fourth largest producer of swine worldwide, producing more than 37 million heads annually (Miranda, 2007). This level of production can produce nearly 300 million liters of liquid swine dejections each day. This represents a production of more than 100 million cubic meters of liquid pig dejections each year. The high volume of swine waste is due to the method of intense swine production that is characterized by confinement of the animals and the use of large volumes of water for the removal of swine dejections (pig slurry) from the production units to a storage tanks.

Swine production has created serious environmental problems due to the inadequate disposal of generated wastes. In many cases, the pig slurry is applied to the soil at high levels and is then able to reach the ground water supply. For this reason, swine production is considered an activity with high environmental risk. This is especially true in the southern states (Paraná, Santa Catarina and Rio Grande do Sul) where almost $50 \%$ of the production occurs in Brazil (Miranda, 2007).

The most commonly used method for recycling the large volume of pig slurry is to apply the dejections to the soil. This reduces the effect of the pollutant and contributes to soil fertilization. Several studies show that the application of pig slurry contributes to increased plant nutrition and productivity (Seganfredo, 2007). However, there are many doubts about the effect of pig slurry on biological soil properties when it is applied at high levels and under different soil tillage systems.

It is well known that disturbing the soil alters the ability of the soil to degrade organic matter. Tilling the soil disrupts soil aggregates and therefore exposes organic matter to microbial degradation. These structural changes can affect soil temperature, aeration, the equilibrium of chemical reactions, and increase the rate of soil erosion. On the other hand, decreased soil tillage can stop soil degradation and improve microbial activity and soil quality (Rahman et al., 2008). The decrease of soil disturbance can change the soil habitat through the formation and stabilization of macroaggregates. This stabilization affects the nutrient status of the soil and can stimulate soil microbial diversity, thereby mediating the mineralization of soil organic matter (SOM) and nutrients (Balota et al., 2004; Green et al., 2007). The microbial biomass comprises approximately $2-5 \%$ of total organic matter, but it represents an important reservoir of nutrients (Aponte et al., 2010; Kaschuk et al., 2010; Miltner et al., 2011). Nutrients are released from microbial cells five times faster than from the decomposition of vegetable residue (Paul \& Clark, 1996). Therefore, the microbial biomass is a fundamental component of nutrient cycling in agro-ecosystems.

Microbial biomass has been utilized as a sensitive indicator of change in soil organic matter due to its fast turnover compared to organic $\mathrm{C}$ and $\mathrm{N}$ (which are unresponsive over short periods) (Carter, 1986; Balota et al., 2003; Babujia et al., 2010). In this context, microbial biomass may be a valuable tool for understanding changes in soil properties and in analyzing the degree of soil degradation or soil quality (Aponte et al., 2010; Kaschuk et al., 2010).

The objective of this work was to evaluate the changes in microbial biomass due to the application of pig slurry under different soil tillage systems.

\section{Material AND METHODS}

The experiment was established in 1996 at the IAPAR Experimental Station in Palotina, west of Paraná State (24 17' $\mathrm{S}, 53^{\circ} 50^{\prime} \mathrm{W}$ ). The soil was clayey Oxisol that is classified as Eutrophic Red Latossol with a composition of $60 \%$ clay, $16 \%$ silt and $24 \%$ sand. The soil had a pH of $5.2\left(\mathrm{CaCl}_{2}\right), 14.8 \mathrm{mg} \mathrm{kg}^{-1}$ of $\mathrm{P}$ (Mehlich) and $20.0 \mathrm{~g} \mathrm{~kg}^{-1}$ of organic carbon (WalkleyBlack) in the surface layer $(0-20 \mathrm{~cm})$.

The experiment was conducted using a split plot design with tillage as the main plot $(100 \times 5 \mathrm{~m})$ and the addition of pig slurry as the subplot $(20 \times 5 \mathrm{~m})$. The plots were separated by a $2.0 \mathrm{~m}$ buffer. The experimental design consisted of blocks with three replicates. Soil tillage treatments were no tillage (NT), which entailed planting into undisturbed soil by opening a narrow trench, or conventional tillage (CT) in which one disc plowed at depth of $20 \mathrm{~cm}$ and the field was lightly harrowed twice for seedbed preparation. The pig slurry was added prior to soil preparation at four levels $\left(0,30,60\right.$ and $120 \mathrm{~m}^{3} \mathrm{ha}^{-1}$ year-1). Half of the doses were applied to the summer crop and the other half to the winter crop. The area was cultivated with soybean (Glycine max L.) and maize (Zea mays L.) in the summer and wheat (Triticum sativum Lam.) or oat (Avena sativa $\mathrm{L}$.) in the winter. Each year, crop stubbles were either retained on the surface in the NT system or conventionally tilled (plowed to 20 $\mathrm{cm}$ depth) following harvest, in both the fall and spring operations.

Five sub-samples of soil were randomly collected within each replicate (0-5, 5-10 and 10-20 cm depths) in March and October of 1998 and 1999 (at the end of the summer and winter crop). Large material was removed from each sample and the soil was then sieved through a $4 \mathrm{~mm}$ screen. The samples were stored at $4{ }^{\circ} \mathrm{C}$ until analysis. Chemical analyses were conducted according to Pavan et al. (1992). The total organic C was determined through the Walkley-Black procedure, where the organic matter is oxidized by potassium dichromate in the presence of sulfuric acid. The remaining dichromate was determined by titration method (Pavan et al., 1992).

The microbial biomass $\mathrm{C}(\mathrm{MBC})$ was determined using the fumigation-extraction method according to Vance et al. (1987) with a correction factor $(\mathrm{kc})$ of 0.33 . The microbial biomass $\mathrm{N}$ (MBN) was determined using the method of Brookes et al. (1985) with a correction factor of 0.54 (Brookes et al., 1985). The microbial biomass P (MBP) was determined using the fumigation-extraction method according to Brookes et al. (1982) with a correction factor $(\mathrm{kp})$ of 0.4 . All the analyses were conducted in triplicate and expressed on a dry weight basis. The metabolic quotient $\left(\mathrm{qCO}_{2}\right)$ was obtained by dividing the respiration of the soil by the microbial biomass $\mathrm{C}\left(\mathrm{mg} \mathrm{CO}_{2}-\mathrm{C} \mathrm{g}^{-1}\right.$ $\mathrm{MBC} \mathrm{d}^{-1}$ ). The microbial biomass $\mathrm{N}$ and $\mathrm{P}$ pools were calculated from the microbial biomass $\mathrm{N}$ and $\mathrm{P}$ concentrations measured 
at each treatment multiplied by the bulk density $\left(1.4 \mathrm{~kg} \mathrm{dm}^{-3}\right)$ and the thickness of soil layer. The annual flux of $\mathrm{N}$ and $\mathrm{P}$ through the microbial biomass was estimated by considering a 1.0 year turnover time for the nutrient stocked in microbial biomass as proposed by Gijsman et al. (1997) for tropical and subtropical environments. Within each treatment, data was averaged over the two seasons and the two years prior to statistical analysis by ANOVA using the SAS statistical package. Microbial biomass for each tillage system and depth were submitted to regression analysis. Significant equation was chosen by $\mathrm{F}$ test $(\mathrm{P} \leq 0,05)$ which presented higher coefficient of determination $\left(\mathrm{R}^{2}\right)$.

\section{RESULTS AND DISCUSSION}

The chemical properties of the soils following three years of the application of the pig slurry under different soil tillage conditions are shown in Table 1.

There was little difference in the organic $\mathrm{C}$ content due to application of pig slurry. However, the treatment with $120 \mathrm{~m}^{3}$ $\mathrm{ha}^{-1}$ year $^{-1}$ of pig slurry increased the organic $\mathrm{C}$ compared to the other doses at three depths both under CT and NT. The application of the liquid pig manure did not alter the $\mathrm{pH}, \mathrm{CEC}$ or base saturation. It also did not affect the $\mathrm{Ca}, \mathrm{Mg}$ and $\mathrm{K}$ content (data not showed).

Figure 1 shows the regression curves and equations for the available phosphorus as affected by the application of increased quantities of pig slurry under conventional or no tillage for the three soil depth intervals studied. The soil $\mathrm{P}$ concentration increased due to the application of the pig slurry under both CT and NT. However, at a depth of 0-5 cm, the increase under NT was twice than of CT. Under NT, each cubic meter of pig slurry increased the level of $\mathrm{P}$ by $0.747 \mathrm{mg}$ $\mathrm{kg}^{-1}$, while under CT the increase was approximately $0.343 \mathrm{mg}$ $\mathrm{kg}^{-1}$ of $\mathrm{P}$ (Figure 1). There was increase of soil $\mathrm{P}$ content due to pig slurry application under both the CT and NT systems;

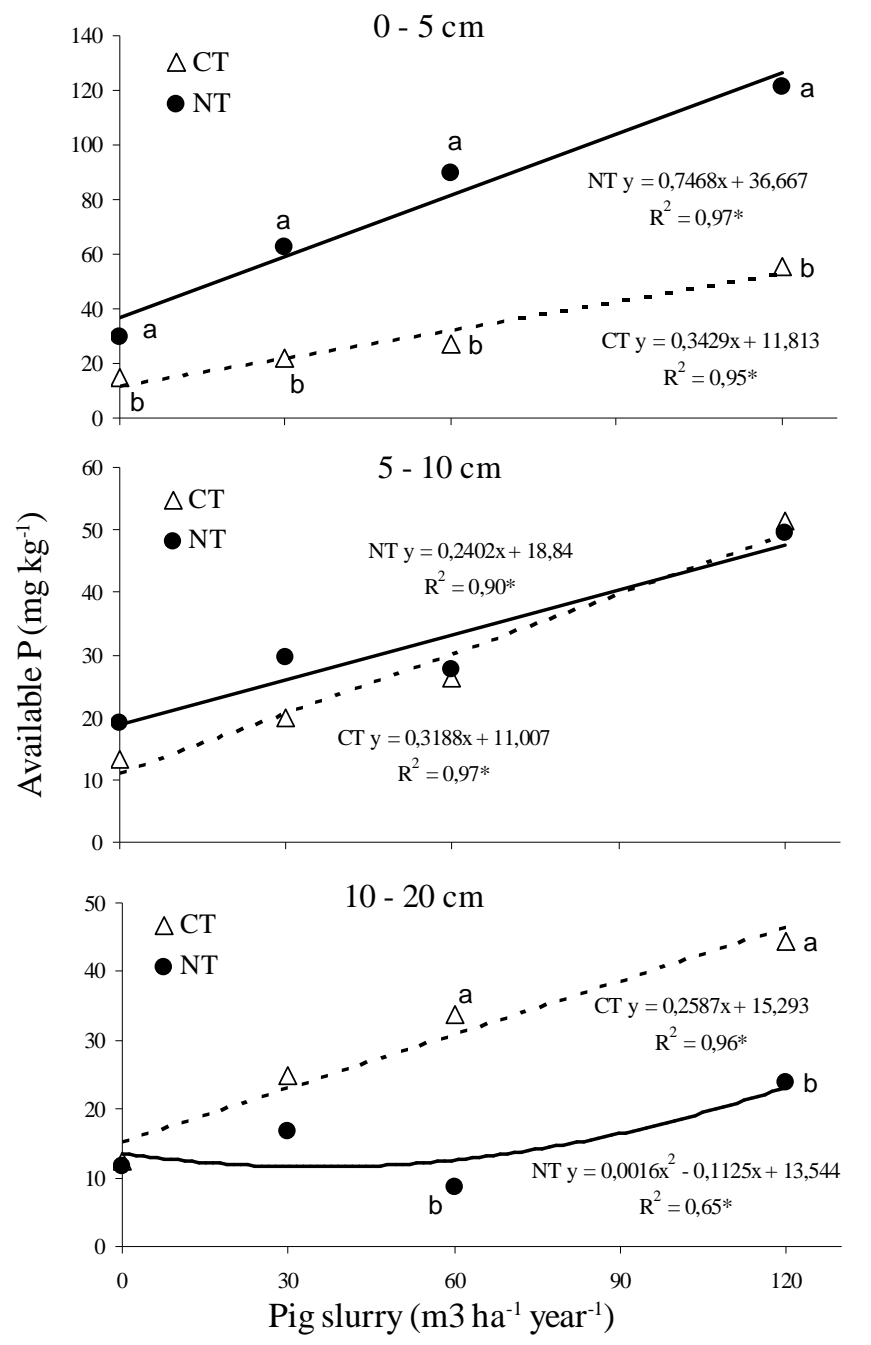

* Significative at $5 \%$ of probability. Values followed by different lower case letter comparing tillage system within a pig slurry dose of the same sample depth are significantly different by the Tukey test $(P \leq 0.05)$

Figure 1. Available phosphorus as affected by the application of increased quantities of pig slurry under conventional or no tillage

Table 1. Soil chemical properties after three years of pig slurry application under conventional tillage (CT) or no tillage (NT)

\begin{tabular}{|c|c|c|c|c|c|c|c|c|}
\hline \multirow{2}{*}{$\begin{array}{c}\text { Pig slurry } \\
\mathrm{m}^{3} \mathrm{ha}^{-1} \text { year }^{-1}\end{array}$} & \multicolumn{2}{|c|}{ Organic C $\left(\mathrm{mg} \mathrm{kg}^{-1}\right)^{1}$} & \multicolumn{2}{|c|}{$\mathrm{pH}^{2}$} & \multicolumn{2}{|c|}{ CEC $\left(\mathrm{cmol}_{\mathrm{c}} \mathrm{kg}^{-1}\right)$} & \multicolumn{2}{|c|}{ Base saturation (\%) } \\
\hline & CT & NT & CT & NT & CT & NT & CT & NT \\
\hline $\begin{array}{r}0 \\
30 \\
60 \\
120 \\
\end{array}$ & $\begin{array}{l}16.4 \mathrm{bB} \\
18.4 \mathrm{abB} \\
16.8 \mathrm{bB} \\
20.5 \mathrm{aB} \\
\end{array}$ & $\begin{array}{l}24.5 \mathrm{abA} \\
23.1 \mathrm{abA} \\
21.9 \mathrm{bA} \\
25.9 \mathrm{aA} \\
\end{array}$ & $\begin{array}{l}0-5 \\
4.9 \\
5.1 \\
4.9 \\
5.2 \\
\end{array}$ & $\begin{array}{r}\text { epth } \\
5.1 \\
5.1 \\
5.1 \\
5.1 \\
\end{array}$ & $\begin{array}{l}13.7 \\
13.8 \\
12.4 \\
15.0 \\
\end{array}$ & $\begin{array}{l}15.0 \\
16.0 \\
14.8 \\
16.3 \\
\end{array}$ & $\begin{array}{l}60.7 \\
63.4 \\
56.9 \\
66.9 \\
\end{array}$ & $\begin{array}{l}64.1 \\
65.6 \\
63.7 \\
64.5 \\
\end{array}$ \\
\hline $\begin{array}{r}0 \\
30 \\
60 \\
120 \\
\end{array}$ & $\begin{array}{l}17.1 \mathrm{bA} \\
18.4 \mathrm{abA} \\
17.0 \mathrm{bA} \\
20.4 \mathrm{aA}\end{array}$ & $\begin{array}{l}19.8 \mathrm{abA} \\
20.2 \mathrm{abA} \\
17.9 \mathrm{bA} \\
22.0 \mathrm{aA}\end{array}$ & $\begin{array}{l}5-10 \\
5.0 \\
5.1 \\
4.9 \\
5.2 \\
\end{array}$ & $\begin{array}{c}\text { lepth } \\
5.0 \\
5.1 \\
5.0 \\
5.2\end{array}$ & $\begin{array}{l}13.6 \\
14.1 \\
13.7 \\
15.1 \\
\end{array}$ & $\begin{array}{l}14.5 \\
15.2 \\
13.4 \\
15.9 \\
\end{array}$ & $\begin{array}{l}60.7 \\
64.0 \\
60.0 \\
66.3\end{array}$ & $\begin{array}{l}62.1 \\
65.4 \\
58.6 \\
66.9\end{array}$ \\
\hline $\begin{array}{r}0 \\
30 \\
60 \\
120\end{array}$ & $\begin{array}{l}16.8 \mathrm{abA} \\
19.2 \mathrm{aA} \\
15.5 \mathrm{bA} \\
19.4 \mathrm{aA}\end{array}$ & $\begin{array}{l}17.1 \mathrm{bcA} \\
18.7 \mathrm{abA} \\
14.9 \mathrm{cA} \\
20.4 \mathrm{aA}\end{array}$ & $\begin{array}{c}10-2 \\
5.0 \\
5.2 \\
5.0 \\
5.2\end{array}$ & $\begin{array}{c}\text { depth } \\
5.0 \\
5.3 \\
5.0 \\
5.4\end{array}$ & $\begin{array}{l}13.7 \\
14.6 \\
13.3 \\
14.3\end{array}$ & $\begin{array}{l}13.6 \\
15.3 \\
13.3 \\
15.2\end{array}$ & $\begin{array}{l}62.1 \\
66.8 \\
61.8 \\
65.2\end{array}$ & $\begin{array}{l}59.6 \\
67.9 \\
60.5 \\
69.7\end{array}$ \\
\hline
\end{tabular}

${ }^{2} \mathrm{pH}\left(\mathrm{CaCl}_{2} 0.01 \mathrm{M}\right)$. Means followed by a different lower case letter within a column of the same depth are significantly different by the Tukey test $(\mathrm{P} \leq 0.05)$. Means followed by a different upper case letter between tillage system (CT and NT) are significantly different by the Tukey test $(\mathrm{P} \leq 0.05)$ 
however, the P content under CT did not show variation with depth. These observations confirm previous results for CT (which disturbs the upper $20 \mathrm{~cm}$ of soil), and demonstrate that under NT (without soil disturbance) there was an accumulation of $\mathrm{P}$ in the surface layer. Even without soil disturbance, there is still movement of $P$ to the sub-surface layers (although the downward P movement in soils is slight) (Eghball et al., 1996).

One of the main factors that may influence $\mathrm{P}$ movement (which occurs mainly in the first few weeks after application) is the phosphorus adsorption capacity of soil. In addition, P from manure moves deeper into the soil than $\mathrm{P}$ from chemical fertilizers; this occurs even at similar P loading rates (Eghball et al., 1996).

In a study using an Ultisol (Typic Hapludalf) containing $24 \%$ clay from Rio Grande do Sul State, the soil received 216 $\mathrm{kg} \mathrm{ha}^{-1}$ of P via a pig slurry. After one year, $64 \%$ of the $\mathrm{P}$ was retained in the soil, $15 \%$ was absorbed by the plants, $4.3 \%$ was lost due to drainage and $0.52 \%$ of $\mathrm{P}$ was lost due to leaching (Basso, 2003). In another study in the same region and soil type (Typic Hapludalf), Berwanger et al. (2008) observed that when pig slurry was applied containing phosphorus levels higher than those removed by crops $\left(40 \mathrm{~m}^{3} \mathrm{ha}^{-1}\right.$ year $\left.^{-1}\right)$, there was downward $P$ movement to a depth of $15 \mathrm{~cm}$ after 4.5 years. Hountin et al. (2000) observed P moved to a depth of $100 \mathrm{~cm}$ after 14 years of applying pig slurry. These results are confirmed by the present study in which the application of pig slurry on the surface layer, compared to the treatment without the application of pig slurry, increased the $\mathrm{P}$ concentration up to $261 \%$ at a depth of $5-10 \mathrm{~cm}$ and $106 \%$ at a depth of $10-20 \mathrm{~cm}$. This is evidence of the downward movement of $\mathrm{P}$ in the soil. Of the total available $P$ at a depth of $0-20 \mathrm{~cm}, 62.3 \%$ accumulated at $0-5 \mathrm{~cm}, 25.5 \%$ at $5-10 \mathrm{~cm}$ and $12.2 \%$ at $10-20 \mathrm{~cm}$. It has been evidenced that the $\mathrm{P}$ (from manure) moved from the soil surface to the sub-surface layers in its organic form. In addition, the chemical reactions of the organic compounds in manure with $\mathrm{P}$ may have enhanced the movement $\mathrm{P}$ to deeper soil (Eghball et al., 1996).

The average values of microbial biomass obtained from twelve samples (four samplings of three replicates each over two years) indicated that the application of pig slurry and soil tillage systems influenced the microbial biomass.

The application of pig slurry had a significant positive effect on the microbial biomass. There was a linear increase in both MBC and MBN as the quantity of the applied pig slurry increased under both the CT and NT treatments (Figures 2 and 3). In general, NT resulted in a higher MBC and MBN than CT. For each cubic meter of pig slurry applied, the increase in $\mathrm{MBC}$ under NT was approximately twice that observed under $\mathrm{CT}$ at all three depths. The MBN at depths of 0-5 cm and 10-20 cm showed similar results; the MBN was higher under NT. However, at a depth of $5-10 \mathrm{~cm}$, there was no difference in the MBN under NT compared to CT.

Microbial biomass $\mathrm{P}$ (MBP) also increased as the quantity of applied pig slurry increased at $0-10 \mathrm{~cm}$ layer. Under the NT system, at a depth of $0-5 \mathrm{~cm}$, the increase in MBP was approximately six times higher than that observed under CT

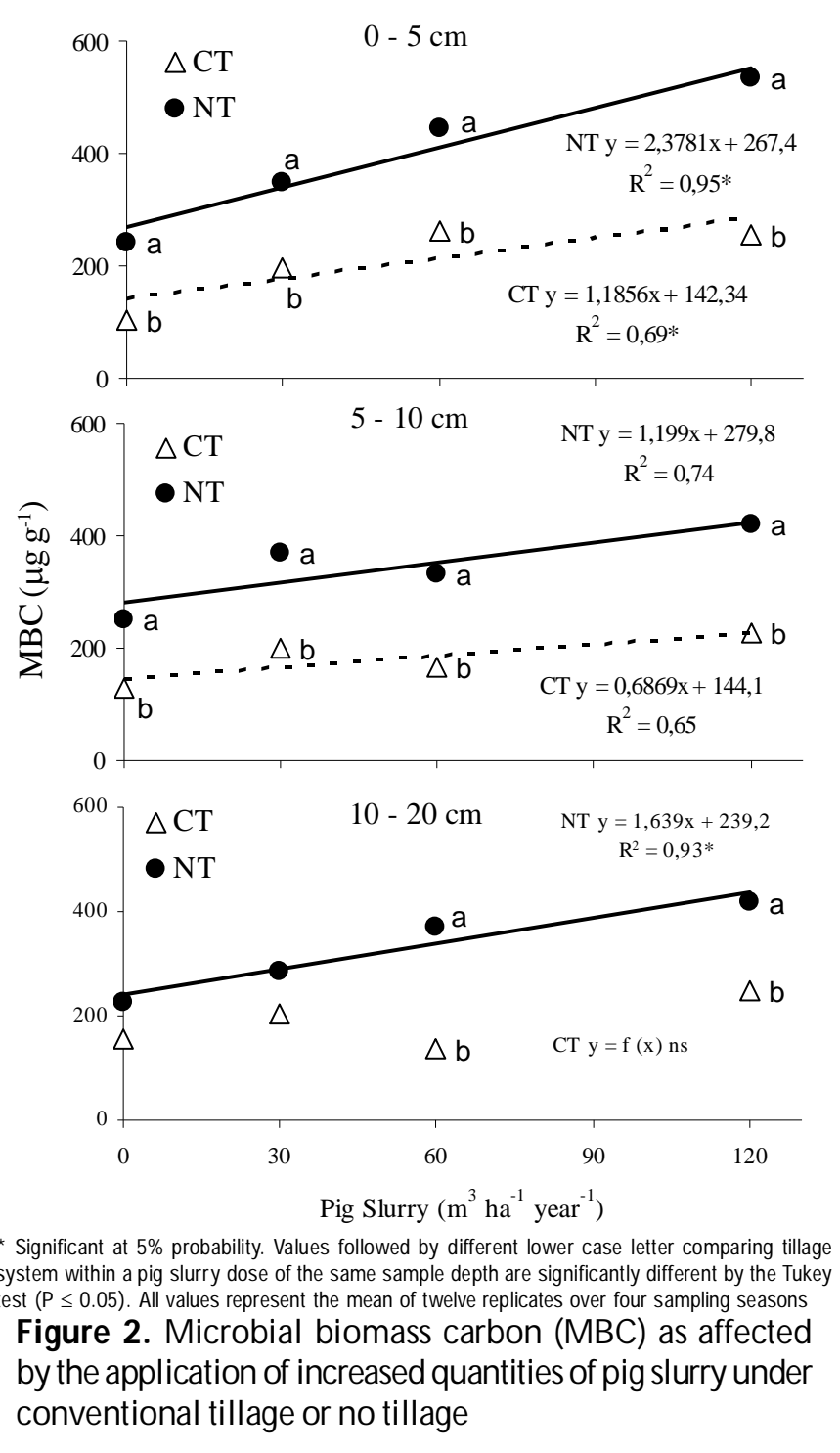

for each quantity of pig slurry applied. However the MBP under CT was also higher than under NT below the surface (at depths of $5-10 \mathrm{~cm}$ and $10-20 \mathrm{~cm}$ ) (Figure 4).

The microbial biomass values obtained in this study are consistent with studies conducted in other regions of Brazil. Values ranged from 72 to $1520 \mu \mathrm{g} \mathrm{g}^{-1}$ for MBC (Kaschuk et al., 2010), from 8 to $110 \mu \mathrm{g} \mathrm{g}^{-1}$ for MBN (Balota et al., 2003; Almeida et al., 2009), and from 4 to $60 \mu \mathrm{g} \mathrm{g}^{-1}$ for MBP (Rheinheimer et al., 2000) under various soil management conditions.

The increase in microbial biomass in response to the addition of pig slurry is consistent with previous studies that showed similar increases after three years (Rochette \& Gregorich, 1998) and nineteen years (Rochette et al., 2000) of pig slurry application. The pig manure also affects the quantity and quality of the microbial communities (Larkin et al., 2006), the $\mathrm{C}$ and $\mathrm{N}$ mineralization (Balota et al., 2010) and the soil enzymes activities (Balota et al., 2011).

A high microbial biomass may indicate an increase in the size of the organic pool. The increase in the microbial biomass $\mathrm{C}, \mathrm{N}$ and $\mathrm{P}$ due to pig slurry application may be in response to a higher nutrient immobilization capacity by the microbial community. The organic manure added to the soil is used as an 

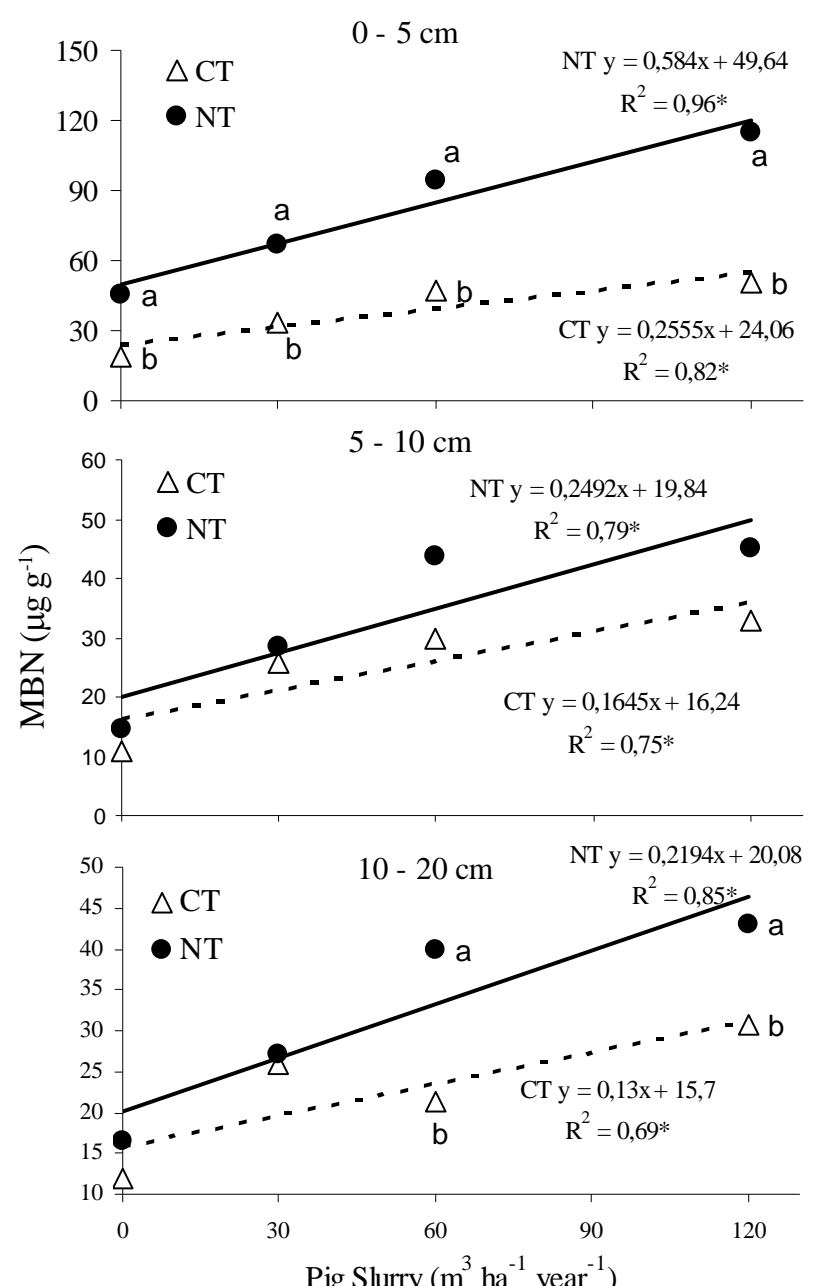

* Significant at $5 \%$ probability. Values followed by different lower case letter comparing tillage system within a pig slurry dose of the same sample depth are significantly different by the Tukey test $(P \leq 0.05)$. All values represent the mean of twelve replicates over four sampling seasons

Figure 3. Microbial biomass nitrogen (M BN) as affected by the application of increased quantities of pig slurry under conventional tillage or no tillage

energy and nutrient source for microorganisms. Pig slurry is a rich source of nutrients in both organic and inorganic forms. For example, on a dry matter basis, the pig slurry contains approximately $3.4 \%$ N, $4.2 \%$ P and 5.6\% K(Oliveira \& Parizotto, 1993) as well as several micronutrients needed for crop production. The inorganic nutrients are readily available for crop growth, while the organic nutrients become gradually available over time. The application of 30,60 and $120 \mathrm{~m}^{3} \mathrm{ha}^{-1}$ year $^{-1}$ of pig slurry is equal to the addition, of 220,440 , and 860 $\mathrm{kg} \mathrm{ha}^{-1}$ of ammonium sulfate, 570, 1140 and $2280 \mathrm{~kg} \mathrm{ha}^{-1}$ of simple superphosphate and 134, 268 and $536 \mathrm{~kg} \mathrm{ha}^{-1}$ of potassium chloride, respectively. Although pig slurry only provides low levels of available carbon (approximately 1\%) for soil microorganisms, it is a source of large amount of nutrients and organic compounds that can stimulate the activity of the microbial biomass. Therefore, depending on soil management, the microbial biomass represents either a sink or source for plant-available nutrients.

The microbial biomass is a small part (5\%) of the SOM, but it is the most labile fraction and has an important role in nutrient cycling. Nutrients are released from microbial cells
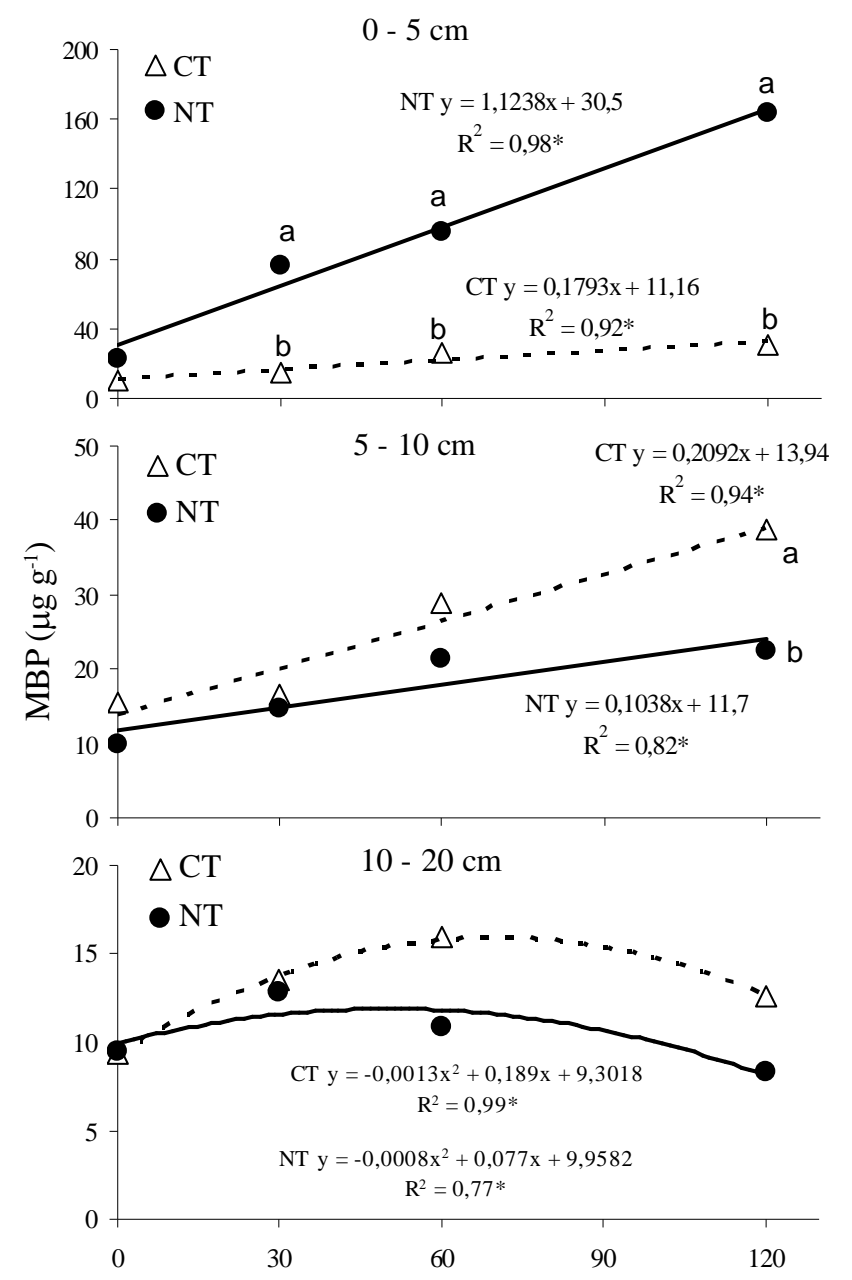

Pig Slurry $\left(\mathrm{m}^{3}\right.$ ha $^{-1}$ year $\left.^{-1}\right)$

* Significant at $5 \%$ probability. Values followed by different lower case letter comparing tillage system within a pig slurry dose of the same sample depth are significantly different by the Tukey test $(P \leq 0.05)$. All values represent the mean of twelve replicates over four sampling seasons

Figure 4. Microbial biomass phosphorus (MBP) as affected by the application of increased quantities of pig slurry under conventional tillage or no tillage

five times faster than from the decomposition of vegetable residue (Paul \& Clark, 1996). On the other hand, approximately $95 \%$ of the SOM is non-living and relatively stable; therefore it may take decades to observe changes due to soil management (Aponte et al., 2010; Miltner et al., 2011). For this reason, the microbial biomass may be used as an index of soil fertility; an increase can reflect the improvement in soil fertility (Sing et al., 2007). In addition, due to its highly dynamic character, the microbial biomass responds more rapidly to soil changes, whereas the physical and chemical properties are relatively slow to change (Balota et al., 2003; Babujia et al., 2010; Kaschuk et al., 2010).

On average, over all the depths, NT presented a higher microbial biomass than CT, increasing $90 \%$ for $\mathrm{MBC}, 68 \%$ for $\mathrm{MBN}$ and $91 \%$ for MBP. This is in agreement with the previous observation that a decrease in soil disturbance improves microbial activity (Balota et al., 2004; Green et al., 2007; Singh et al., 2007; Franchini et al., 2007). It is well known that CT, which uses plowing and disking to prepare the land, reduces soil organic 
Table 2. Microbial biomass $\mathrm{C} / \mathrm{N}, \mathrm{C} / \mathrm{P}$ and $\mathrm{N} / \mathrm{P}$ ratios at a depth of $0-10 \mathrm{~cm}$ as affected by the application of increased quantities of pig slurry under conventional tillage (CT) or no tillage* (NT)

\begin{tabular}{|c|c|c|c|c|c|c|}
\hline \multirow{2}{*}{$\begin{array}{c}\text { Pig slurry } \\
\mathrm{m}^{3} \mathrm{ha}^{-1} \text { year }\end{array}$} & \multicolumn{2}{|c|}{ C / N Ratio } & \multicolumn{2}{|c|}{ C / P Ratio } & \multicolumn{2}{|c|}{ N / P Ratio } \\
\hline & СТ & NT & CT & NT & CT & NT \\
\hline 0 & $8.7 \mathrm{aB}$ & $11.3 \mathrm{aA}$ & $9.1 \mathrm{abB}$ & $17.8 \mathrm{aA}$ & $1.26 \mathrm{bB}$ & $1.72 \mathrm{aA}$ \\
\hline 30 & $6.8 \mathrm{abB}$ & $9.1 \mathrm{bB}$ & $12.6 \mathrm{aB}$ & $14.8 \mathrm{abA}$ & $1.89 \mathrm{aA}$ & $1.41 \mathrm{bA}$ \\
\hline 60 & $5.5 \mathrm{bA}$ & $6.2 \mathrm{cA}$ & $7.9 \mathrm{bB}$ & $10.0 \mathrm{bA}$ & $1.43 \mathrm{abA}$ & $1.51 \mathrm{abA}$ \\
\hline 120 & $5.9 \mathrm{bA}$ & $6.9 \mathrm{cA}$ & $7.0 \mathrm{bB}$ & $11.0 \mathrm{bA}$ & 1.23 bA & $1.36 \mathrm{bA}$ \\
\hline
\end{tabular}

* Average of 24 samples, over two depths, from four sampling seasons and three replicates. Means followed by a different lower case letter within a column and means followed by a different upper case letter between tillage system (CT and NT) are significantly different by the Tukey test $(P \leq 0,05)$

matter (particularly in tropical conditions). Disturbing the soil degrades soil aggregates and results in the reduction of soil structure and increases the oxidation of organic matter. Soil macroaggregates are an important mechanism for the protection and maintenance of soil organic matter (SOM) that can be lost under CT (Beare et al., 1994). The changes in the soil habitat due to soil disturbance can decrease the microbial community (Rahman et al., 2008). The lack of soil disturbance, as when using NT, can provide a steady source of organic $\mathrm{C}$ to support the microbial community. Furthermore, decreasing the level of soil disturbance favors the formation and stabilization of macroaggregates to improve and protect the habitat for microbiota (Beare et al., 1994) and improves soil quality. Several studies show that, in the long term, disturbing the soil causes a decline in organic matter due to the deterioration of the soil's physical, chemical and biological properties.

There was little effect on the $\mathrm{C} / \mathrm{N}, \mathrm{C} / \mathrm{P}$ and N/P microbial biomass ratios in response to different quantities of applied pig slurry or the soil tillage systems. However when analyzed, on average, at the $0-10 \mathrm{~cm}$ depth, the microbial biomass ratios $\mathrm{C} / \mathrm{N}, \mathrm{C} / \mathrm{P}$ and N/P decreased as the quantity of applied pig slurry increased (Table 2). The $\mathrm{C} / \mathrm{N}$ microbial biomass ratio varied from 5.5 to 8.7 under CT and from 6.2 to 11.3 under NT. The C/P ratio varied from 7.0 to 12.6 under $\mathrm{CT}$ and from 10.0 to 17.8 under NT. The N/P microbial biomass ratio varied from 1.26 to 1.89 under $\mathrm{CT}$ and from 1.36 to 1.72 under NT.

The $\mathrm{C} / \mathrm{N}, \mathrm{C} / \mathrm{P}$ and N/P microbial biomass ratios observed in this study were within the normal range reported in the literature. They ranged from 2.2 to 14.1 for C/N (Smith \& Paul, 1990; Balota et al., 2003), from 5.0 to 276 for C/P (Joergensen et al., 1995; He et al., 1997) and from 1.0 to 12.2 for N/P (Singh \& Singh, 1993; Aponte et al., 2010).

The changes in the microbial biomass ratios are evidence that the composition of the soil microbial community and the rate of immobilization and mineralization of soil nutrients have been affected by the soil tillage and by the application of pig slurry. The microbial biomass ratio $(\mathrm{C} / \mathrm{N}$ and $\mathrm{C} / \mathrm{P})$ may be used to indicate the potential impact of the microbial biomass on the availability of $\mathrm{N}$ and $\mathrm{P}$ in the soil (He et al., 1997). Low C/N and $\mathrm{C} / \mathrm{P}$ ratios show that the biomass was enriched in $\mathrm{N}$ and $\mathrm{P}$ and has the high potential to release these nutrients by mineralization. On the other hand, high ratios suggest the potential for the biomass to immobilize available nutrients from the soil.

Variations in the microbial biomass $\mathrm{C} / \mathrm{N}$ ratio may indicate changes in the microbial composition during the decomposition processes and reflect changes in the pattern of microbial immobilization (Smith \& Paul, 1990).
Soil microbial biomass is a composite of several groups of organisms that have different $\mathrm{C} / \mathrm{N}$ ratios. The predominance of one group will result in the prevalence of a particular ratio. The fungal $\mathrm{C} / \mathrm{N}$ ratio is in the range from 7 to 12 while that of bacteria is usually from 3 to 6 (Paul \& Clark, 1996). Plant residues left on the soil surface may stimulate the fungal population, while incorporation of straw encourages bacterial dominance. The $\mathrm{C} / \mathrm{N}$ ratio under $\mathrm{NT}$ was $24 \%$ higher than the $\mathrm{C} / \mathrm{N}$ ratio under NT and therefore suggests that the NT sites had a greater proportion of fungi compared to the CT sites.

These results demonstrate that tillage and the application of pig slurry has a strong impact on the incorporation of $\mathrm{N}$ and $\mathrm{P}$ into the microbial biomass. The lower microbial $\mathrm{C} / \mathrm{P}$ ratio under NT (approximately 60\%) compared to CT confirms previous observations that microbial $\mathrm{C} / \mathrm{P}$ ratios depend strongly on the P status in the soil (Conte et al., 2002; Martinazzo et al., 2007; DeForest et al., 2011). Under NT, the average available $\mathrm{P}$ content was almost three times higher than $\mathrm{CT}$. The higher $\mathrm{P}$ content under NT may be the reason for the lower microbial C/P ratio. Lower microbial $\mathrm{C} / \mathrm{P}$ ratios indicate that the microbial biomass was significantly enriched in $\mathrm{P}$ and has a higher potential to release this nutrient via mineralization.

The metabolic quotient $\left(\mathrm{qCO}_{2}\right)$ varied from 41 to $97 \mathrm{mg} \mathrm{CO}_{2}-\mathrm{C}$ $\mathrm{g}^{-1} \mathrm{MBC} \mathrm{d}^{-1}$ under $\mathrm{CT}$ and 27 to $68 \mathrm{mg} \mathrm{CO}_{2}-\mathrm{C} \mathrm{g}^{-1} \mathrm{MBC} \mathrm{d}^{-1}$ under NT. There was a decrease in the $\mathrm{qCO}_{2}$ as the quantities of applied pig slurry increased under NT at the depths of $0-5 \mathrm{~cm}$ and $5-10 \mathrm{~cm}$ (in spite of the increase in the MBC). Under CT, this inverse relationship was not observed (data not shown). The relationship between $\mathrm{MBC}$ and $\mathrm{qCO}_{2}$ was similar to that obtained previously in same soil type submitted to different tillage (Balota et al., 2004) and at organic and conventional farming systems in Northeast Brazil (Araújo et al., 2008). The variations in the $\mathrm{qCO}_{2}$ may be due to differences in the accessibility of $\mathrm{C}$ substrates by microorganisms, changes in the metabolic rates, and changes in the composition of the microbial community.

On average, over all pig slurry application levels, the $\mathrm{qCO}_{2}$ under CT increased with depth, while under NT there was decrease (Figure 5). The $\mathrm{qCO}_{2}$ under NT decreased approximately $24 \%$ compared to CT. It has been suggested that the $\mathrm{qCO}_{2}$ decreases in more stable systems. This result suggests that an increase in the amount of applied pig slurry at the surface layer under NT may result in a more efficient microbial community. This is demonstrated by the increase in microbial biomass associated with the decrease of $\mathrm{C}$ released from the soil. This has important implications for sustainable agriculture because if less $\mathrm{C}$ is released from the soil, more $\mathrm{C}$ can be stored in soil organic matter. This is possible because 


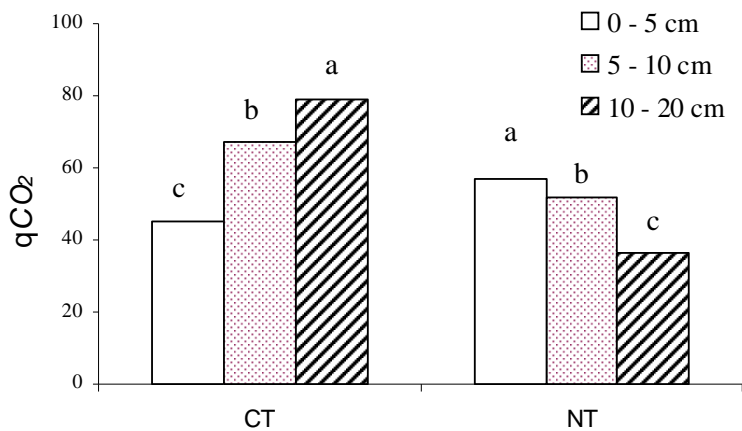

* Different lower case letters within the tillage systems and upper case letters between the tillage systems express significant differences by the Tukey test $(P \leq 0.05)$. Average of 48 samples, over four levels of liquid pig manure application, four sampling seasons and three replicates

Figure 5. The metabolic quotient $\left(\mathrm{qCO}_{2}\right)$ under different depths and soil tillage systems

under NT a greater amount of aggregates may be created that protect microorganisms from adverse conditions. This result also may be due to the fact that the lack of soil disturbance associated with the application of pig slurry provides a shift towards a more fungal-dominated microbial community. Fungi typically assimilate available $\mathrm{C}$ into biomass more readily than bacteria. Therefore, bacterial communities are less efficient at converting substrate $\mathrm{C}$ into cellular $\mathrm{C}$ than fungi.

On average, in all depths sampled, there was an increase in the relation of microbial biomass $\mathrm{C}$ to organic $\mathrm{C}\left(\mathrm{C}_{\mathrm{mic}}: \mathrm{C}_{\text {org }}\right)$, except for $120 \mathrm{~m}^{3} \mathrm{ha}^{-1}$ year-1, as the amount of applied pig slurry increased (Figure 6). The results show an interaction between soil tillage and pig slurry, with quadratic model due to the quantity of applied pig slurry. The $\mathrm{C}_{\text {mic }}: \mathrm{C}_{\text {org }}$ relation varied from $0.77 \%$ to $1.22 \%$ under CT and from $1.19 \%$ to $2.12 \%$ under NT. NT provided a significant increase in the $\mathrm{C}_{\text {mic }}: \mathrm{C}_{\text {org }}$ relation under all levels of applied pig manure compared to $\mathrm{CT}$. These increases were $54,51,86$ and $65 \%$ at $0,30,60$ and $120 \mathrm{~m}^{3} \mathrm{ha}^{-1}$ year ${ }^{-1}$ of applied pig slurry, respectively. Over all levels of applied pig slurry, NT presented an average $\mathrm{C}_{\text {mic }}: \mathrm{C}_{\text {org }}$ relation that was $58 \%$ higher than CT.

The values obtained in this study are similar to those observed under different soil conditions and management

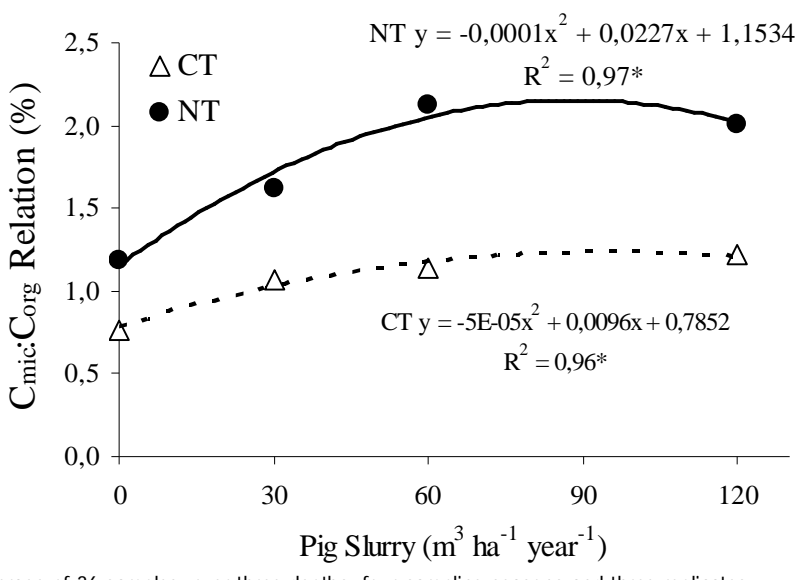

Average of 36 samples, over three depths, four sampling seasons and three replicates

Figure 6. The $C_{\text {mic }}: C_{\text {org }}$ relation at $0-20 \mathrm{~cm}$ depth as affected by the application of increased quantities of liquid pig manure under conventional tillage or no tillage systems in other regions of Paraná State (using the same analytical methods) (Balota et., 2004; Balota \& Chaves, 2011). The wide range for this relationship due to soil management may suggest its high sensibility to express $\mathrm{C}$ turnover pattern.

The percentage of total $\mathrm{C}$ as $\mathrm{MBC}$ is related to efficiency of the conversion of recalcitrant $\mathrm{C}$ pools into $\mathrm{MBC}$. For this reason, the $\mathrm{C}_{\text {mic }}: \mathrm{C}_{\text {org }}$ relation may be an indicator if the amount of soil organic matter is decreasing, increasing or at a steady state. It has been suggested that a $\mathrm{C}_{\text {mic }}: \mathrm{C}_{\text {org }}$ relation of $2.2 \%$ is representative of a soil in equilibrium (Jenkinson \& Ladd, 1981). In this study, treatments that demonstrated a $\mathrm{C}_{\text {mic }}: \mathrm{C}_{\text {org }}$ relation higher than $1.10 \%$, also showed an increase in the organic carbon. An exception was seen at the level of $60 \mathrm{~m}^{3} \mathrm{ha}^{-1}$ year $^{-1}$ of applied pig slurry; in spite of a high $\mathrm{C}_{\text {mic }}: \mathrm{C}_{\text {org }}$ relation $(2.12 \%)$ under NT, the organic carbon decreased by $8.5 \%$. This level of applied pig slurry $\left(60 \mathrm{~m}^{3} \mathrm{ha}^{-1}\right.$ year $\left.^{-1}\right)$ appears to provide particular conditions not observed compared to the other treatment levels; the majority of microbial variables studied presented a typical behavior under this treatment. The relationship between the $\mathrm{C}_{\text {mic }}: \mathrm{C}_{\text {org }}$ relation and organic carbon was quite low $\left(\mathrm{R}^{2}=0.31\right.$ for $\mathrm{CT}$ and $\mathrm{R}^{2}=0.011$ for $\left.\mathrm{NT}\right)$, however when the $60 \mathrm{~m}^{3} \mathrm{ha}^{-1}$ year-1 treatment level is eliminated, the relationship becomes quite high $\left(\mathrm{R}^{2}=0.98 *\right.$ for $\mathrm{CT}$ and $\mathrm{R}^{2}=$ $0.78 *$ for NT). The fact that the different levels of applied pig slurry affect the soil differently suggests that the $\mathrm{C}_{\text {mic }}: \mathrm{C}_{\text {org }}$ relation may have a different threshold as an indicator of $\mathrm{C}$ accumulation under tropical and/or subtropical conditions compared to temperate regions.

There were relationships between the microbial variables, soil organic $\mathrm{C}$, the $\mathrm{C}_{\text {mic }}: \mathrm{C}_{\text {org }}$ relation and the P content (Table 3). A high correlation between microbial biomass and organic $\mathrm{C}$ was previously observed by Balota et al. (2003), Araújo et al. (2008) and Balota \& Chaves (2011). The significant relationship between microbial biomass and organic $\mathrm{C}$ is likely due to the fact that higher organic matter levels support greater microbial biomass and activity. This also suggests that microbial biomass is interconnected with soil C cycling.

Table 3. Correlation ( $r$ ) between microbial and chemical properties across all treatments and depths

\begin{tabular}{lccccc}
\hline Variables & Organic C & MBC & MBN & MBP & $\mathbf{C}_{\text {mic }}: \mathbf{C}_{\text {org }}$ \\
MBC & $0.63^{*}$ & - & - & - & \\
MBN & $0.70^{*}$ & $0.79 *$ & - & - & \\
MBP & $0.67^{*}$ & $0.62^{*}$ & $0.91^{*}$ & - & \\
$\mathrm{C}_{\text {mic }}: C_{\text {org }}$ & 0.29 & $0.91^{*}$ & 0.60 & 0.37 & \\
Available P & $0.75^{*}$ & $0.65^{*}$ & $0.89 *$ & $0.92^{*}$ & 0.37 \\
\hline P - extractable (Mehlich). * significantly at P $\leq 0,05$ & & &
\end{tabular}

There was high correlation between microbial biomass $\mathrm{P}$ and available $\mathrm{P}(\mathrm{r}=0.92 * *)$. Similar results were previously observed by Conte et al. (2002), Martinazzo et al. (2007) and DeForest et al. (2011) where the MBP was increased due to the addition of $\mathrm{P}$ to the soil. However, the MBP fraction is not always determined by the size of the P pool. The MBP may be also increased due to the combination of a recent addition of phosphate fertilizer along with a large addition of $\mathrm{C}$ from decomposing plant residues (Conte et al., 2002).

The estimates of the microbial $\mathrm{N}$ and $\mathrm{P}$ pools (based on the microbial biomass content) considering the first $20 \mathrm{~cm}$ layer 
suggest that these pools are large enough to have significant impacts on plant nutrient availability. The average $\mathrm{N}$ content of the microbial biomass pool is from 39 to $107 \mathrm{~kg} \mathrm{ha}^{-1}$ under CT and from 71 to $190 \mathrm{~kg} \mathrm{ha}^{-1}$ under NT. The average P content in microbial biomass pool is from 33 to $77 \mathrm{~kg} \mathrm{ha}^{-1}$ under CT and from 39 to $181 \mathrm{~kg} \mathrm{ha}^{-1}$ under NT. Assuming a turnover time of 1.0 year for microbial nutrients (Gijsman et al., 1997), the annual nutrient flux through the soil microbial biomass was as high as $107 \mathrm{~kg} \mathrm{ha}^{-1}$ of $\mathrm{N}$ under CT and as high as $190 \mathrm{~kg} \mathrm{ha}^{-1}$ of $\mathrm{N}$ under NT. The annual Pflux was as high as $77 \mathrm{~kg} \mathrm{ha}^{-1}$ of P for CT and $181 \mathrm{~kg} \mathrm{ha}^{-1}$ of P for NT. These values represent a large part of the $\mathrm{N}$ and $\mathrm{P}$ necessary for annual crop growth. Although the microbial biomass turnover time varies widely (from 0.10 to 4.76 year) under different condition in the world, Gijsman et al. (1997) consider a value around 1.0 year as a reasonable estimate for tropical and subtropical condition.

These results demonstrate that the microbial biomass represents a substantial reserve of nutrients for agricultural crops. The microbes immobilize a significant amount of nutrients. They thereby decrease the pools of free nutrients and consequently prevent their losses via leaching. The microbial biomass can release nutrients slowly in conjunction with plant nutrient demand. However, the total quantity of nutrients mineralized through microbial biomass is not available exclusively for crop growth. The nutrients may be used by the next generation of microorganisms or adsorbed onto soil colloids. Nevertheless, the results clearly show that the soil microbial biomass represents an important nutrient source for agricultural crops.

Our results demonstrate that analysis of the microbial biomass present a suitable mechanism to detect soil alterations due to soil tillage and the application of pig slurry. Although swine dejectis have the potential to be detrimental to the environment, it can also improve soil quality and serve as an excellent source of nutrients for crop production. The increase in microbial activity can promote soil structure and aggregation which would in turn, improve several other desirable soil qualities. However, swine slurry must only be applied after carefully calculating the correct application rate. The land application rate can be determined by matching the available nutrients (mainly $\mathrm{N}$ and $\mathrm{P}$ ) of the manure with the nutrient requirements of crops. The capacity of the soil to receive pig slurry (which may vary due to the soil clay/sand content and the slope gradient) must also be considered. If all of these conditions have been considered, the soil can serve as a mechanism to recycle the pig slurry while the manure increases the microbial activity in the soil and provides a significant source of nutrients for crops.

\section{Conclusions}

1. The soil tillage and the pig slurry influenced the microbial biomass $\mathrm{C}, \mathrm{N}$ and $\mathrm{P}$.

2. The application of the pig slurry increased the microbial biomass $\mathrm{C}, \mathrm{N}$ and $\mathrm{P}$ and the $\mathrm{C}_{\text {mic }}: \mathrm{C}_{\text {org }}$ relation.

3. The metabolic quotient was increased with depth under CT and was decreased under NT.
4. The soil microbial biomass was enriched in $\mathrm{N}$ and $\mathrm{P}$ under NT due to the application of pig slurry.

5. The microbial biomass and its activity provide a sensitive mechanism to detect changes in the soil due to tillage and the application of pig slurry.

\section{LiTERATURE CITED}

Almeida, D.; Klauberg Filho, O.; Felipe, A. F.; Almeida, H. C. Carbono, nitrogênio e fósforo microbiano do solo sob diferentes coberturas em pomar de produção orgânica de maçã no sul do Brasil. Bragantia, v.68, p.1069-1077, 2009.

Aponte, C.; Marañon, T.; Garcia, L. V. Microbial C, N and Pin soils of Mediterranean oak forests: Influence of season, canopy cover and soil depth. Biogeochemistry, v.101, p.77-92, 2010.

Araújo, A. S. F.; Santos, V. B.; Monteiro, R. T. R. Responses of soil microbial biomass and activity for practices of organic and conventional farming systems in Piauí state, Brazil. European Journal of Soil Biology, v.44, p.225-230, 2008.

Babujia, L. C.; Hungria, M.; Franchini, J. C.; Brookes, P. C. Microbial biomass and activity at various soil depths in a Brazilian oxisol after two decades of no-tillage and conventional tillage. Soil Biology \& Biochemistry, v.42, p.2174-2181, 2010.

Balota, E. L.; Chaves, J. C. D. Microbial activity in soil cultivated with different summer legumes in coffee crop. Brazilian Archives of Biology and Technology, v.54, p.35-44, 2011.

Balota, E. L.; Colozzi-Filho, A.; Andrade, D. S.; Dick, R. P. Microbial biomass in soils under different tillage and crop rotation systems. Biology and Fertility of Soils, v.38, p.15-20, 2003.

Balota, E. L.; Colozzi-Filho, A.; Andrade, D. S.; Dick, R. P. Longterm tillage and crop rotation effects on microbial biomass and $\mathrm{C}$ and $\mathrm{N}$ mineralization in a Brazilian Oxisol. Soil \& Tillage Research, v.77, p.137-145, 2004.

Balota, E. L.; Machineski, O.; Truber, P. V. Soil carbon and nitrogen mineralization caused by pig slurry application under different soil tillage systems. Pesquisa Agropecuária Brasileira, v.45, p.515-521, 2010.

Balota, E. L.; Machineski, O.; Truber, P. V. Soil enzyme activities under pig slurry addition and different tillage systems. Acta Scientiarum Agronomy, v.33, p.729-737, 2011.

Basso, C. J. Perdas de nitrogênio e fósforo com aplicação no solo de dejetos líquidos de suínos. UFSM: Santa Maria, 2003. 125p. Tese Doutorado

Beare, M. H.; Cabrera, M. L.; Hendrix, P. F.; Coleman, D. C. Aggregate-protected and unprotected organic matter pools in conventional and no-tillage soils. Soil Science Society of America Journal, v.58, p.787-795, 1994.

Behera, B.; Singh, R. I.; Xess, I.; Mathur, P.; Hasan, F.; Misra, M. C. Candida rugosa: A possible emerging cause of candidaemia in trauma patients. Infection, v.38, p.387-393, 2010.

Berwanger, A. L.; Ceretta, C. A.; Santos, D. R. Alterações no teor de fósforo no solo com aplicação de dejetos líquidos de suínos. Revista Brasileira de Ciência do Solo, v.32, p.2525$2531,2008$. 
Brookes, P. C.; Landman, A.; Pruden, G.; Jenkinson, D. S. Chloroform fumigation and the release of soil nitrogen: a rapid direct extraction method to measure microbial biomass nitrogen in soil. Soil Biology \& Biochemistry, v.17, p.837$842,1985$.

Brookes, P. C.; Powlson, D. S.; Jenkinson, D. S. Measurement of microbial biomass phosphorus in the soil. Soil Biology \& Biochemistry, v.14, p.319-329, 1982.

Carter, M. R. Microbial biomass as an index for tillage-induced changes in soil biological properties. Soil \& Tillage Research, v.7, p.29-40, 1986.

Conte, E.; Anghinoni, I.; Rheinheimer, D. S. Fósforo da biomassa microbiana e atividade de fosfatase ácida após aplicação de fosfato em solo no sistema plantio direto. Revista Brasileira de Ciência do Solo, v.26, p.925-930, 2002.

DeForest, J. L.; Smemo, K. A.; Burke, D. J.; Elliott, H. L.; Becker, J. C. Soil microbial responses to elevated phosphorus and $\mathrm{pH}$ in acidic temperate deciduous forests. Biogeochemistry, v.22, p.1-14, 2011.

Eghball, B.; Binford, G. D.; Baltensperger, D. D. Phosphorus movement and adsorption in a soil receiving long-term manure and fertilizer application. Journal of Environmental Quality, v.25, p.1339-1343, 1996.

Franchini, J. C.: Crispino, C. C.: Souza, R. A.: Torres, E.; Hungria, M. Microbiological parameters as indicators of soil quality under various tillage and crop rotation systems in southern Brazil. Soil \& Tillage Research, v.92, p.18-29. 2007.

Gijsman, A. J.; Oberson, A.; Friesen, D. K.; Sanz, J. I.; Thomas, R. J. Nutrient cycling through microbial biomass under ricepasture rotations replacing native savanna. Soil Biology \& Biochemistry, v.29, p.1433-1414, 1997.

Green, V. S.; Stott, D. E.; Cruz, J. C.; Curi, N. Tillage impacts on soil biological activity and aggregation in a Brazilian Cerrado Oxisol. Soil \& Tillage Research, v.92, p.114-121, 2007.

He, Z. L.; Wu, J.; O`Donnel, A. G.; Syers, J. K. Seasonal responses in microbial biomass carbon, phosphorus and sulphur in soils under pasture. Biology and Fertility of Soils, v.24, p.421-428, 1997.

Hountin, J. A.; Karan, A.; Couillard, D.; Cescas, M. P. Use of a fractionation procedure to assess the potential for $\mathrm{P}$ movement in a soil profile after 14 years of liquid pig manure fertilization. Agriculture, Ecosystems and Environmental, v.78, p.77-84, 2000.

Jenkinson, D. S.; Ladd, J. N. Microbial biomass in soil: Measurement and turnover. In: Paul, E.A., Ladd, J. M. (ed.) Soil Biochemistry, 5. NewYork: Marcel Decker, 1981. p.415471.

Joergensen, R. G.; Kübler, H.; Meyer, B.; Wolters, V. Microbial biomass phosphorus in soils of beech (Fagus sylvatica) forests. Biology and Fertility of Soils, v.19, p.215-219, 1995.

Kaschuk, G.; Alberton, O.; Hungria, M. Três décadas de estudos sobre biomassa microbiana nos ecossistemas brasileiros: Lições aprendidas sobre qualidade do solo e indicadores de sustentabilidade. In: Reunião Brasileira de Fertilidade do Solo e Nutrição de Plantas, 29, 2010. Guarapari, Anais... Guarapari: Fertibio, 2010. CD-Rom
Larkin, R. P.; Honeycutt, C. W.; Griffin, T. S. Effect of swine and dairy manure amendments on microbial communities in three soils as influenced by environmental conditions. Biology and Fertility of Soils, v.43, p.51-61, 2006.

Martinazzo, R.; Rheinheimer, D. S.; Gatiboni, L. C.; Brunetto, G.; Kaminski, J. Fósforo microbiano do solo sob sistema plantio direto em resposta à adição de fosfato solúvel. Revista Brasileira de Ciência do Solo, v.31, p.563-570, 2007.

Miltner, A.; Bombach, P.; Schmidt-Brücken, B.; Kästner, M. Som genesis: Microbial biomass as a significant source. Biogeochemistry, v.22, p.139-143, 2011.

Miranda, C. R. Aspectos ambientais da suinocultura brasileira. In: Gestão ambiental na suinocultura, Seganfredo, M. A. (ed.). Brasília: EMBRAPA, 2007. p.14-36.

Oliveira, E.; Parizotto, M. L. V. Características e uso fertilizante do esterco de suíno. IAPAR: 1993. 24p. Circular, 83

Paul, E. A.; Clark, F. E. Soil Microbiology and biochemistry. San Diego: Academic Press, 1996. 340p.

Pavan, M. A.; Bloch, M. de F.; Zempulski, H. C.; Miyazawa, M.; Zocoler, D. C. Manual de análise química de solo e controle de qualidade. Londrina: IAPAR, 40p. 1992. Circular técnica, 76

Rahman, M. H.; Okubo, A.; Sugiyama, S.; Mayland, H. F. Physical, chemical and microbiological properties of an Andisol as related to land use and tillage practice. Soil \& Tillage Research, v.101, p.10-19, 2008.

Rheinheimer, R. S.; Anghinoni, I.; Conte, E. Fósforo da biomassa microbiana em solos sob diferentes sistemas de manejo. Revista Brasileira de Ciência do Solo, v.24, p.589-597, 2000.

Rochette, P.; Angers, D. A.; Côté, D. Soil carbon nitrogen dynamics following application of pig slurry for the $19^{\text {th }}$ consecutive year: I-Carbon dioxide fluxes and microbial biomass carbon. Soil Science Society of America Journal, v.64, p.1389-1395, 2000.

Rochette, P.; Gregorich, G. Dynamis of soil microbial biomass $\mathrm{C}$, soluble organic $\mathrm{C}$ and $\mathrm{CO}_{2}$ evolution after three years of manure application. Canadian Journal of Soil Science, v.78, p.283-290, 1998.

Seganfredo, M. A. Uso de dejetos suínos como fertilizante e seus riscos ambientais. In: Gestão ambiental na suinocultura, Seganfredo, M.A. (ed.). Brasília: EMBRAPA, 2007. p.150175.

Singh, H.; Singh, K. P. Effect of residue placement and chemical fertilizer on soil microbial biomass under tropical dryland cultivation. Biology and Fertility of Soils, v.16, p.275-281, 1993.

Singh, S.; Ghoshal, N.; Singh, K. P. Variations in soil microbial biomass and crop roots due to differing resource quality inputs in a tropical dryland agroecosystem. Soil Biology \& Biochemistry, v.39, p.76-86, 2007.

Smith, J. L.; Paúl, E. A. The significance of microbial biomass estimations. In: Bollag, J. M.; Stozky, G. (ed.) Soil Biochemistry. New York: Marcel Decker. 1990. p.357-396.

Vance, E. D.; Brookes, P. C.; Jenkinson, D. S. An extraction method for measuring soil microbial biomass carbon. Soil Biology \& Biochemistry, v.19, p.703-707, 1987. 